\title{
Mucosal and blood-brain barrier transport kinetics of the plant $N$-alkylamide spilanthol using in vitro and in vivo models
}

\author{
Lieselotte Veryser ${ }^{1}$, Lien Taevernier ${ }^{1}$, Tanmayee Joshi ${ }^{2}$, Pratima Tatke², Evelien Wynendaele ${ }^{1}$, Nathalie Bracke ${ }^{1}$, \\ Sofie Stalmans ${ }^{1}$, Kathelijne Peremans ${ }^{3}$, Christian Burvenich ${ }^{4}$, Martijn Risseeuw ${ }^{5}$ and Bart De Spiegeleer ${ }^{1 *}$
}

\begin{abstract}
Background: N-alkylamides (NAAs) are a large group of secondary metabolites occurring in more than 25 plant families which are often used in traditional medicine. A prominent active NAA is spilanthol. The general goal was to quantitatively investigate the gut mucosa and blood-brain barrier (BBB) permeability pharmacokinetic properties of spilanthol.

Methods: Spilanthes acmella (L.) L. extracts, as well as purified spilanthol were used to investigate (1) the permeation of spilanthol through a Caco-2 cell monolayer in vitro, (2) the absorption from the intestinal lumen after oral administration to rats, and (3) the permeation through the BBB in mice after intravenous injection. Quantification of spilanthol was performed using a validated bio-analytical UPLC-MS ${ }^{2}$ method.

Results: Spilanthol was able to cross the Caco-2 cell monolayer in vitro from the apical-to-basolateral side and from the basolateral-to-apical side with apparent permeability coefficients $P_{\text {app }}$ between $5.2 \cdot 10^{-5}$ and $10.2 \cdot 10^{-5} \mathrm{~cm} / \mathrm{h}$. This in vitro permeability was confirmed by the in vivo intestinal absorption in rats after oral administration, where an elimination rate constant $\mathrm{k}_{\mathrm{e}}$ of $0.6 \mathrm{~h}^{-1}$ was obtained. Furthermore, once present in the systemic circulation, spilanthol rapidly penetrated the blood-brain barrier: a highly significant influx of spilanthol into the brains was observed with a unidirectional influx rate constant $K_{1}$ of $796 \mu l /(g \cdot m i n)$.
\end{abstract}

Conclusions: Spilanthol shows a high intestinal absorption from the gut into the systemic circulation, as well as a high BBB permeation rate from the blood into the brain.

Keywords: Plant N-alkylamide spilanthol, Caco-2 cells, Oral absorption, Blood-brain barrier

\section{Background}

$\mathrm{N}$-alkylamides (NAAs) are a large group of secondary metabolites occurring in more than 25 plant families, often used in traditional medicine and claimed to possess a diverse range of pharmacological activities such as antimicrobial, analgesic and anti-inflammatory properties [1-8]. The NAAs consist of a short-chain amine linked to an aliphatic chain of poly-unsaturated fatty acids through a central peptide amide bond. Spilanthol (affinin; deca-2E,6Z,8Etrienoic acid isobutylamide; F3M1 according to the FxMy classification of NAAs) is a highly abundant and biologically potent triene NAA found in Asteracea

\footnotetext{
* Correspondence: Bart.DeSpiegeleer@UGent.be

${ }^{1}$ Drug Quality and Registration (DruQuaR) group, Faculty of Pharmaceutical Sciences, Ghent University, Ottergemsesteenweg 460, B-9000 Ghent, Belgium Full list of author information is available at the end of the article
}

plants such as Spilanthes acmella. Traditionally, Spilanthes acmella plants are not only used as a food spice, in toothpastes and cosmetics, but have also been used in folk medicine for the treatment of toothaches, stomatitis, rheumatism, fever, funal skin infections and diverse pain and neuropathic disorders [8]. The pharmacological central nervous system (CNS) activity and physiological mechanisms of spilanthol are only fragmentary documented. Chakraborty et al. [9] and Barman et al. [10] reported a central analgesic activity of a subcutaneously Spilanthes acmella extract in an in vivo rat tail flick experiment. Rios et al. [11] showed that a Heliopsis longipes extract, in which spilanthol was the main active compound, evoked cortical GABA (gamma-aminobutyric acid) release in an ex vivo in vitro mice brain-tissue study. 
In order to exert these CNS effects, these compounds must be able to cross several physiological barriers in the human body. Using in vitro Franz diffusion cell (FDC) experiments, it has already been shown that the $N$-alkylamide spilanthol can permeate the human skin and pig oral mucosa, reaching the systemic circulation after topical application [12-14]. The permeability coefficient $\mathrm{K}_{\mathrm{p} \text {,aq }}$ was $3.31 \cdot 10^{-3} \mathrm{~cm} / \mathrm{h}$ for human skin and $11.3 \cdot 10^{-3} \mathrm{~cm} / \mathrm{h}$ for the porcine buccal mucosa.

After oral administration, compounds must be able to pass through the intestinal barrier to reach the systemic circulation. Matthias et al. [15] investigated the transport of mainly diene $N$-alkylamides from Echinacea (E. angustifolia and E. purpurea root) through a Caco-2 cell monolayer, which is a model of the intestinal barrier, and found that after $90 \mathrm{~min}$, more than $50 \%$ of the NAAs permeated through the monolayer.

Once present in the blood by passsage through the skin or mucosa, compounds can cross the blood-brain barrier to exert central nervous system effects. This entry of compounds into the brain is strictly regulated and controlled: the BBB forms not only a physical barrier (tight junctions), but also a transport and metabolic barrier (enzymes) to maintain an adequate microenvironment of the neuronal cells [16]. A previous study indicated that tetraene NAAs from Echinacea appeared in the brains after a single oral dose of $2.5 \mathrm{mg} / \mathrm{kg}$ to rats [17].

Up till now, there is no information about the transport kinetics of the 2,6,8-triene $N$-alkylamide spilanthol through the intestinal barrier after oral application and through the blood-brain barrier, once present in the blood. Therefore, the aim of this study was to quantitatively investigate the intestinal permeability (in vitro Caco- 2 cell monolayer and in vivo oral gavage rat model) and the $\mathrm{BBB}$ transport kinetics (in vivo mice model) of spilanthol. Moreover, the distribution of spilanthol within the $\mathrm{BBB}$, i.e. brain parenchyma versus endothelial cells, was investigated.

\section{Methods}

\section{Chemicals and reagents}

Ultrapure water $\left(\mathrm{H}_{2} \mathrm{O}\right)$ of $18.2 \mathrm{M} \Omega . \mathrm{cm}$ quality was produced by an Arium 611 purification system (Sartorius, Göttingen, Germany). Vitamin E-TPGS, Hanks' Balanced Salt Solution (HBSS), trypan blue, potassium chloride $(\mathrm{KCl})$, dimethylsulfoxide (DMSO), phosphate buffered saline (PBS), sodium chloride $(\mathrm{NaCl})$, calcium chloride dehydrate $\left(\mathrm{CaCl}_{2} \cdot 2 \mathrm{H}_{2} \mathrm{O}\right)$, sodium lactate, dichloromethane, sodium hydrogen carbonate $\left(\mathrm{NaHCO}_{3}\right)$, sodium sulphate $\left(\mathrm{Na}_{2} \mathrm{SO}_{4}\right)$, sodium dihydrogen phosphate $\left(\mathrm{NaH}_{2} \mathrm{PO}_{4}\right)$, hydrochloric acid $(\mathrm{HCl})$ and urethane were purchased from Sigma-Aldrich (Diegem, Belgium), while bovine serum albumin (BSA), disodium hydrogen phosphate dehydrate $\left(\mathrm{Na}_{2} \mathrm{HPO}_{4} \cdot 2 \mathrm{H}_{2} \mathrm{O}\right)$, sodium dihydrogen phosphate monohydrate $\left(\mathrm{NaH}_{2} \mathrm{PO}_{4} \cdot \mathrm{H}_{2} \mathrm{O}\right)$, sodium hydrogen carbonate and absolute ethanol $(\geq 99.9 \% \mathrm{~V} / \mathrm{V})$ were obtained from Merck KGaA (Darmstadt, Germany). Absolute ethanol (99.8 \% V/V), HPLC gradient grade methanol $(\mathrm{MeOH})$ and acetonitrile $(\mathrm{ACN})$ came from Fisher Scientific (Erembodegem, Belgium). Dextran was obtained from AppliChem GmbH (Darmstadt, Germany). UPLCMS grade $\mathrm{MeOH}$ and $\mathrm{ACN}$ were bought from Biosolve (Valkenswaard, the Netherlands). Phosphoric acid (85\%) $\left(\mathrm{H}_{3} \mathrm{PO}_{4}\right)$ and dimethylacetamide were purchased from Jansen Chimica (Geel, Belgium). Trypsin-EDTA was obtained from Invitrogen (Ghent, Belgium). Calcium dichloride $\left(\mathrm{CaCl}_{2}\right)$, LC-MS grade formic acid (FA), polyethylene glycol 400 (PEG 400), tween 80, D-glucose, sodium hydroxide $(\mathrm{NaOH})$ and HEPES were purchased at Fluka (Diegem, Belgium) while propylene glycol (PG) was bought from Riedel-de Haën (Seelze-Hannover, Germany). Triethylamine, decanoyl chloride and isobutylamine were purchased at Acros Organics (Geel, Belgium). The BBBpositive control dermorphin was purchased at Bachem (Bubendorf, Switzerland). NMR solvents were bought from Eurisotop (Saint-Aubin, France).

\section{Products examined}

The ethanolic Spilanthes acmella (L.) L. flowers extract (batch 0001853516, $30 \%$ w/w spilanthol in ethanol) was obtained from Robertet (Grasse, France) and was used for the BBB transport assay. Spilanthes acmella (L.) L. is also known as Akarkara (local name) and Para Cress (English name). HPLC analysis confirmed the spilanthol content, as well as a small quantity (9\%) of other NAAs [14]. The Spilanthes acmella (L.) L. extract (A. Vogel, label claim indicated $2 \% \mathrm{w} / \mathrm{w}$ dry residue of extracts in $69 \% \mathrm{~V} / \mathrm{V}$ ethanol; internal assay: $0.11 \% \mathrm{w} / \mathrm{w}$ spilanthol, purity >90\%) came from Bioforce AG (Switzerland) and was used for the oral gavage experiment.

Purified spilanthol was used for the Caco-2 cell permeability assay. Semi-preparative HPLC was used for its purification as follows: the Spilanthes acmella (L.) L. extract of Robertet was dissolved in 30:70 (V/V) $\mathrm{H}_{2} \mathrm{O}$ :ethanol and filtered using a $0.45 \mu \mathrm{m}$ nylon HPLC filter (Whatman). One $\mathrm{ml}$ of this solution was injected on a Vydac C18 monomeric semi-preparative column (Grace, $250 \mathrm{~mm}$ x $10 \mathrm{~mm}$, $5 \mu \mathrm{m}$ particle size, $300 \AA$ pore size) using a Waters HPLC, equipped with a Waters 2487 Dual Absorbance Detector. The sample compartment and column temperature were maintained at room temperature. An isocratic elution mode was used with a 50:50 (V/V) A:B (A: 0.1 \% FA in $\mathrm{H}_{2} \mathrm{O}$ and $\mathrm{B}: 0.1 \% \mathrm{FA}$ in $\left.\mathrm{MeOH}\right)$ mobile phase. A flow rate of $6.0 \mathrm{ml} / \mathrm{min}$ was used and UV detection was performed at $237 \mathrm{~nm}$. Fractions between 16 and 32 min retention time were collected and lyophilized using a Christ Gamma 1-16 LSC freeze-dryer (Q-lab, Vilvoorde, Belgium). The purity of the isolated spilanthol was determined by analytical HPLC-UV at $237 \mathrm{~nm}$ [12] and was $99.9 \%$. 
As analytical internal standard (IS) in the bio-analytics, isobutyldecanamide was used and synthesised as described in Fig. 1. The NMR spectra of this internal standard can be retrieved in Additional file 1.

Triethylamine $(6.0 \mathrm{mmol}, 608 \mathrm{mg}, 837 \mu \mathrm{l})$ was added to a solution of isobutylamine $(6.0 \mathrm{mmol}, 439 \mathrm{mg}, 597 \mu \mathrm{l})$ in dichloromethane $(30 \mathrm{ml})$. The mixture was cooled to $0{ }^{\circ} \mathrm{C}$ using an ice bath. Decanoyl chloride $(5.0 \mathrm{mmol}, 954 \mathrm{mg}$, $1.0 \mathrm{ml}$ ) was slowly added to the solution. The mixture was stirred overnight, allowing the temperature to rise to room temperature. The reaction mixture was extracted with $50 \mathrm{ml}$ dichloromethane which was washed successively with $\mathrm{HCl}\left(1.0 \mathrm{M}\right.$ aq.) and $\mathrm{NaHCO}_{3}$ (sat. aq.). The organic layer was dried on $\mathrm{Na}_{2} \mathrm{SO}_{4}$, filtered and concentrated in vacuo to yield the title compound ( $1.07 \mathrm{~g}, 4.7 \mathrm{mmol}$ ) as an off-white waxy solid. The compound was identified by ${ }^{1} \mathrm{H}$ and ${ }^{13} \mathrm{C}$ NMR recorded with a Varian Mercury-300BB $(300 / 75 \mathrm{MHz})$ spectrometer. Chemical shifts are given relative to tetramethylsilane $(0 \mathrm{ppm}){ }^{1} \mathrm{H}$ NMR $(300 \mathrm{MHz}$, $\left.\mathrm{CDCl}_{3}\right): \delta 5.47(\mathrm{~s}, 1 \mathrm{H}), 3.07(\mathrm{t}, J=6.45 \mathrm{~Hz}, 2 \mathrm{H}), 2.16(\mathrm{t}$, $J=7.44 \mathrm{~Hz}, 2 \mathrm{H}), 1.80-1.69(\mathrm{~m}, 1 \mathrm{H}), 1.68-1.58(\mathrm{~m}, 2 \mathrm{H})$ $1.38-1.18(\mathrm{~m}, 12 \mathrm{H}), 0.90(\mathrm{~d}, J=6.90 \mathrm{~Hz}, 6 \mathrm{H}), 0.87(\mathrm{t}, \mathrm{J}=$ $6.90 \mathrm{~Hz}, 3 \mathrm{H}) ;{ }^{13} \mathrm{C}$ NMR $\left(75 \mathrm{MHz}, \mathrm{CDCl}_{3}\right): \delta 173.25,46.92$, $37.16,32.00,29.61,29.51,29.47,29.41,28.67,26.05,22.80$, 20.24, 14.24.

\section{In vitro permeation study in Caco-2 cell monolayers Cell culture}

Caco-2 cells, originating from a human colorectal carcinoma were maintained in Dulbecco's modified Eagle's medium (DMEM) at $95 \%$ humidity and $37{ }^{\circ} \mathrm{C}$ in an atmosphere of $5 \% \mathrm{CO}_{2}$, supplemented with $10 \%$ (V/V) fetal bovine serum, $2 \mathrm{mM}$ L-glutamine and $1 \%$ nonessential amino acids (100x), $100 \mathrm{U} / \mathrm{ml}$ penicillin and $100 \mu \mathrm{g} / \mathrm{ml}$ streptomycin (all from Invitrogen/GIBCO, Ghent, Belgium).

\section{Caco-2 cell permeability assay}

The Caco- 2 cell intestinal model was used as a model for the gut mucosa to investigate the permeation of spilanthol. Caco- 2 cells were seeded at a density of $2.6 \cdot 10^{5}$ cells $/ \mathrm{cm}^{2}$ cells for each Transwell (Corning Costar, New York, USA) membrane insert filter $(0.4 \mu \mathrm{m}$ pore size, $12 \mathrm{~mm}$ filter diameter) and cultivated in the described supplemented DMEM, also containing 100 units/ml penicillin and $100 \mu \mathrm{g} / \mathrm{ml}$ streptomycin. The medium was changed every second day. The cells were allowed to grow and differentiate for 21-29 days until monolayers were formed. Intact membranes/integrity of the monolayers were checked via the measurement of transepithelial electrical resistance (TEER) of the monolayers using the Millicell-ERS system (Millipore Corp., Bedford, MA, USA) before and after transport experiments. The experiment was performed in duplicate for each dose solution. Transport experiments were carried out in the apical-tobasolateral $(\mathrm{ab})$ direction and in the basolateral-to-apical (ba) direction in Hanks' Balanced Salt solution, according to Hubatsch et al. [18]. Two dose solutions of purified spilanthol at $10 \mu \mathrm{g} / \mathrm{ml}$ were tested, differing in solvent: $0.5 \%$ ethanol (further indicated as DS1) and $0.5 \%$ of a mixture of vitamin E-TPGS (33.3 \%), ethanol (11.1\%), PEG 400 (33.3\%) and PG (22.2 \%) (further indicated as DS2) dissolved in HBSS.

Final volumes of $0.4 \mathrm{ml}$ apically and $1.2 \mathrm{ml}$ basolaterally were used for 12-mm filter supports during the transport experiment. Samples were taken at 15, 30, 60, 90 and $120 \mathrm{~min}$ from the acceptor (= receiver) compartment (basolateral to apical transport: $100 \mu \mathrm{l}$; apical to basolateral transport: $300 \mu \mathrm{l}$ ) and were immediately replaced by fresh HBSS. At the last time point, a sample from the donor compartment was taken as well, allowing to obtain the mass balance, which for spilanthol ranged between 104.7 and $120.9 \%$ total recovery. Atenolol $(50 \mu \mathrm{M})$ and propranolol $(20 \mu \mathrm{M})$ were used as the low- and high-permeability control, respectively, confirming the validity of the test [19]. Quantification of spilanthol was conducted using the UPLC-MS ${ }^{2}$ method as described below.

The apparent permeability coefficient $\left(\mathrm{P}_{\text {app }}\right.$ in $\left.\mathrm{cm} / \mathrm{s}\right)$ of spilanthol was calculated from a non-sink equation. From Fick's first law: $\mathrm{J}=-\mathrm{D} \times[\mathrm{dC}(\mathrm{x})] / \mathrm{dx}$ ( $\mathrm{D}$ is the diffusion coefficient, $\mathrm{J}$ is the flux or transfer rate along the donor-to-receptor side, $\mathrm{x}$ is the distance from the donor compartment and $\mathrm{C}(\mathrm{x})$ is the concentration in the barrier at the coordinate $\mathrm{x}$ in the barrier), the following differential equation is derived: $\mathrm{dM}_{\mathrm{r}}(\mathrm{t}) / \mathrm{dt}=\mathrm{P}_{\mathrm{app}} \times \mathrm{A} \times\left[\mathrm{C}_{\mathrm{d}}(\mathrm{t})-\mathrm{C}_{\mathrm{r}}(\mathrm{t})\right]$, in which $M_{r}$ is the amount of substance in the receiver chamber, $\mathrm{P}_{\text {app }}$ is the apparent permeability coefficient (a product of distribution coefficient with diffusion coefficient divided by the barrier thickness), $\mathrm{A}$ is the cross-sectional area of

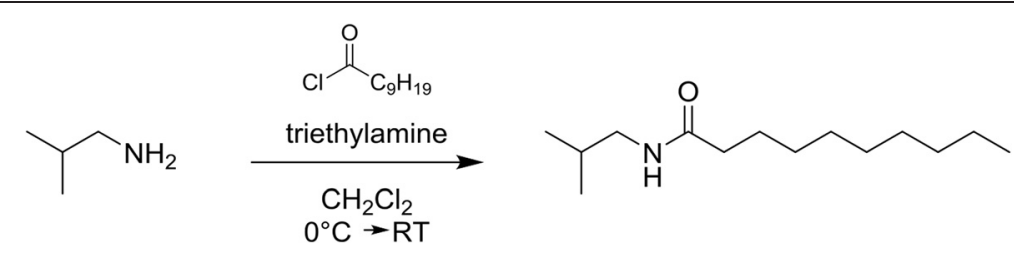

Fig. 1 Synthesis of isobutyldecanamide (analytical internal standard) 
the barrier, $C_{d}$ is the donor concentration and $C_{r}$ is the receiver concentration. This differential equation is the basis to calculate $\mathrm{P}_{\text {app }}$ values of compounds requiring sink, as well as non-sink conditions with different initial conditions to solve this equation. In the case of non-sink conditions, this resulted in the following solution $[18,20]$ :

$C_{r}(t)=\left[\frac{M}{V_{d}+V_{r}}\right]+\left(C_{r, t-1} \times f-\left[\frac{M}{V_{d}+V_{r}}\right]\right) \times e^{-P_{\text {app }} \times A \times\left(\frac{1}{V_{d}}+\frac{1}{V_{r}}\right) \times \Delta t}$

in which $\mathrm{t}$ is the time $(\mathrm{s}), \mathrm{V}_{\mathrm{d}}$ is the volume of the donor compartment $(\mathrm{ml}), \mathrm{V}_{\mathrm{r}}$ the volume of the receiver compartment $(\mathrm{ml}), \mathrm{A}$ the area of the filter $\left(=1.12 \mathrm{~cm}^{2}\right), \mathrm{M}$ the total amount of spilanthol in the system at time $t$ $(\mu \mathrm{g}), \mathrm{C}_{\mathrm{r}, \mathrm{t}-1}$ the concentration of spilanthol in the receiver compartment at the previous time point $(\mu \mathrm{g} / \mathrm{ml}), \mathrm{f}$ is the sample replacement dilution factor $\left(1-V_{s} / V_{r}\right.$ with $V_{s}$ is the sample volume), $\Delta \mathrm{t}$ is the time at time $\mathrm{t}$ minus the previous time point $(\mathrm{s})$ and $\mathrm{C}_{\mathrm{r}}(\mathrm{t})$ the concentration of spilanthol in the receiver compartment at time $\mathrm{t}(\mu \mathrm{g} / \mathrm{ml})$. Non-linear curve fitting by minimisation of the sum of squared residuals (SSR) was used to obtain the $\mathrm{P}_{\text {app }}$. The efflux ratio is calculated as $\mathrm{P}_{\mathrm{app}, \mathrm{ba}} / \mathrm{P}_{\mathrm{app}, \mathrm{ab}}$, while the uptake ratio is calculated as $\mathrm{P}_{\mathrm{app}, \mathrm{ab}} / \mathrm{P}_{\mathrm{app}, \mathrm{ba}}$.

\section{In vivo pharmacokinetic experiment with rats Animals}

The Wistar rats were bred in Bharat Serum and Vaccines pvt. Ltd, Thane, India (registration number 103/ 99/CPCSEA) and kept for the experiments at C. U. Shah College of Pharmacy, SNDT Women's University, Santacruz, Mumbai, India (registration number 39/99/ CPCSEA). The half of the rats used in the experiment were female rats and the other half male rats. Rats of 7 8 weeks old, weighing $220 \mathrm{~g}$, and fasted overnight were used for the experiment.

\section{Pharmacokinetic experiment}

The pharmacokinetic oral gavage experiment was carried out at C. U. Shah College of Pharmacy, SNDT Women's University, Santacruz, Mumbai, India. A spilanthol dose solution was prepared with the Spilanthes acmella (L.) L. extract (A.Vogel). $1.5 \mathrm{ml}$ of a spilanthol dose solution of $0.73 \mathrm{mg}$ spilanthol/g dose solution in 10:20:30:40 (w/w/w/ w) ethanol:PG:vitamin E-TPGS:PEG400 was administered to the rats using a gavage needle made up of stainless steel (length 3 inches and $2.5 \mathrm{~mm}$ internal diameter). A blank dose solution was used as well, containing ethanol, PG, vitamin E-TPGS and PEG without spilanthol. For each dose solution, six rats were used of which three were females and three males. Blood was collected $(1.5 \mathrm{ml})$ from the retro orbital vein at specified time points i.e. 1, 2, 3, 4, 6 , and $8 \mathrm{~h}$ after oral administration of the dose solution. The collected blood samples were centrifuged using a
Remi R-24 centrifuge. At the end of the study, the animals were sacrificed by $\mathrm{CO}_{2}$ inhalation. All samples were immediately frozen at $-80{ }^{\circ} \mathrm{C}$ until bio-analysis. The elimination rate constant was calculated using a one compartmental model using GraphPad software (La Jolla, USA), using the following equation: $\mathrm{C}(\mathrm{t})=\mathrm{C}_{0} \times \mathrm{e}^{-\mathrm{k}_{\mathrm{e}} \times \mathrm{t}}$, in which $\mathrm{t}$ is time (h), $C_{0}$ the concentration of spilanthol at time $t=0(\mathrm{ng} / \mathrm{ml})$, $\mathrm{C}(\mathrm{t})$ the concentration of spilanthol at time $t$ and $\mathrm{k}_{\mathrm{e}}$ the elimination rate constant $\left(\mathrm{h}^{-1}\right)$. The elimination half-life (h) is computed as $\ln (2) / \mathrm{k}_{\mathrm{e}}$.

\section{In vivo blood-brain barrier experiment with mice Animals}

Female, Institute for Cancer Research, Caesarean Derived-1 (ICR-CD-1) mice (Harlan Laboratories, Venray, Netherlands) of age 7-10 weeks and weighing 29-32 g, were used during the $\mathrm{BBB}$ transport experiments. All animal experiments were performed in accordance with the Ethical Committee principles of laboratory animal welfare as approved by our institute (Ghent University, Faculty of Veterinary Medicine, no. EC2012/157 and no. EC2014/128).

\section{Blood-to-brain transport}

An in vivo multiple time regression (MTR) analysis was performed to investigate if spilanthol was able to cross the BBB. A dose solution of spilanthol was prepared using the Spilanthes acmella (L.) L. extract (Robertet) with a final concentration of $4 \mathrm{mg} / \mathrm{ml}$ spilanthol dissolved in $7.0 \%$ ethanol, $2.5 \%$ dimethylacetamide, $0.6 \%$ tween 80 (all w/w) diluted in lactated Ringer's solution containing $1 \%$ BSA. The ICR-CD-1 mice were anesthetized by intraperitoneal injection with a $40 \%(w / V)$ urethane solution $(3 \mathrm{~g} / \mathrm{kg})$ and the jugular internalis vein and carotid artery were isolated, $20 \mu \mathrm{l}$ of the spilanthol dose solution was injected into the jugular vein. Blood was obtained from the carotid artery at regular time points after injection $(1,3,5,10,12.5$ and $15 \mathrm{~min}$, with start and end in duplicate), and the mice were immediately thereafter decapitated. After sacrificing the mice, the brains were collected. The collected blood from the carotid artery was centrifuged at $10000 \mathrm{~g}$ for $15 \mathrm{~min}$ at $21{ }^{\circ} \mathrm{C}$, resulting in serum. In order to assure the validity of the MTR method, ${ }^{125}$ I-BSA and dermorphin diluted in lactated Ringer's solution containing $1 \%$ BSA were used as the negative and positive control, respectively [21-23]. Furthermore, to evaluate the functional BBB integrity under our experimental conditions, ${ }^{125} \mathrm{I}$-BSA was also administered to the mice in a solution containing the same surfactant and co-solvents in equal concentrations as in the spilanthol dose solution. The serum profile of spilanthol was plotted against the time (expressed in min). The curve was fitted using the same one compartmental model as described in the pharmacokinetic 
experimental section. In order to determine the $\mathrm{BBB}$ permeability of a compound, the ratio of the brain and serum concentration $(\mu \mathrm{l} / \mathrm{g})$ was plotted versus a derived time variable, i.e. the exposure time $(\theta)$ of the GjeddePatlak plot $[24,25]$.

The exposure time is defined as the integral of the concentration of spilanthol in serum from start $(t=0 \mathrm{~min})$ to time $\mathrm{T}$, divided by the concentration of spilanthol in serum at time T: $\theta=\int_{0}^{\mathrm{T}} \frac{\mathrm{C}_{\mathrm{S}}(\mathrm{t}) \cdot \mathrm{dt}}{\mathrm{C}_{\mathrm{S}}(\mathrm{T})}$. The integral of the concentration of spilanthol in serum from zero to time $\mathrm{T}$ is the area under the curve until time $\mathrm{T}$.

A biphasic model of blood-brain transfer was used to fit the uptake, as elaborated by Wong et al. [26]:

$$
\begin{aligned}
\frac{\mathrm{C}_{\text {brain }}(\mathrm{T})}{\mathrm{C}_{\mathrm{S}}(\mathrm{T})}=\mathrm{K} \times \theta+\mathrm{V}_{\mathrm{g}} \times\left(1-\mathrm{e}^{\left(-\theta \times\left(\frac{\mathrm{K}_{1}-\mathrm{K}}{\mathrm{V}_{\mathrm{g}}}\right)\right)}\right) & \\
+\mathrm{V}_{0} \stackrel{\mathrm{K}}{ } \cong 0 & \cong \mathrm{V}_{\mathrm{g}} \times\left(1-\mathrm{e}^{\left(-\theta \times\left(\frac{\mathrm{K}_{1}}{\mathrm{~V}_{\mathrm{g}}}\right)\right)}\right)+\mathrm{V}_{0}
\end{aligned}
$$

where $K_{1}$ is the unidirectional clearance $(\mu \mathrm{l} /(\mathrm{g} \cdot \mathrm{min})), \mathrm{K}$ is the net clearance $(\mu \mathrm{l} /(\mathrm{g} \cdot \mathrm{min})), \mathrm{V}_{\mathrm{g}}$ the tissue brain distribution volume $(\mu \mathrm{l} / \mathrm{g})$, and $\mathrm{V}_{0}$ the vascular brain distribution volume $(\mu \mathrm{l} / \mathrm{g})$. The negative control BSA has a low vascular distribution volume and this value $(14.8 \mu \mathrm{l} / \mathrm{g})$ is used as $V_{0}$ to calculate the brain kinetic parameters of spilanthol. In the equation, $C_{\text {brain }}(T)$ is the concentration of spilanthol in the brain at time $\mathrm{T}(\mathrm{ng} / \mathrm{g})$ and $\mathrm{C}_{\mathrm{s}}(\mathrm{T})$ the concentration of spilanthol in serum at time $\mathrm{T}(\mathrm{ng} / \mu \mathrm{l})$.

\section{Capillary depletion}

To investigate the distribution of spilanthol in the parenchyma and capillaries of the brain, a capillary depletion experiment was performed. By means of this experiment, it is possible to distinguish the transport of spilanthol into the brain (represented by the parenchyma) and part of spilanthol which is trapped by the endothelial cells of the brain (represented by the capillaries). The method of Triguero et al. [27], as modified by Gutierrez et al. [28], was used [29]. Briefly, after anesthetizing the mice intraperitoneally with $40 \%(\mathrm{w} / \mathrm{V})$ urethane solution $(3 \mathrm{~g} / \mathrm{kg})$, $20 \mu \mathrm{l}$ of the $4 \mathrm{mg} / \mathrm{ml}$ spilanthol dose solution was injected into the jugular vein. Blood was collected from the abdominal aorta ten min after injection and serum was obtained by centrifuging the blood at $10000 \mathrm{~g}$ during $15 \mathrm{~min}$ at $21^{\circ}$ C. Immediately after blood collection, the skin of the mice's chest is removed to clamp the aorta and the jugular veins are severed. Immediately after clamping the aorta, the brain is perfused manually with $20 \mathrm{ml}$ of Lactated Ringer's solution. The mice are decapitated immediately after perfusion and brain is collected. The brains were put into an Eppendorf tube and weighed. $525 \mu$ ice-cold capillary buffer (10 mM HEPES, $141 \mathrm{mM} \mathrm{NaCl}, 4 \mathrm{mM}$ $\mathrm{KCl}, 2.8 \mathrm{mM} \mathrm{CaCl}_{2}, 1 \mathrm{mM} \mathrm{MgSO}_{4}, 1 \mathrm{mM} \mathrm{NaH}_{2} \mathrm{PO}_{4}$ and $10 \mathrm{mM}$ D-glucose adjusted to $\mathrm{pH}$ 7.4) was added and homogenized. Then, $1000 \mu \mathrm{l}$ of $26 \%$ ice-cold dextrane solution in capillary buffer was added and vortexed. The Eppendorf tube was centrifuged at $20000 \mathrm{~g}$ for $60 \mathrm{~min}$ at $4{ }^{\circ} \mathrm{C}$. Pellet (capillaries) and supernatant (parenchyma and fat tissues) were separately collected into an Eppendorf tube and weighed. The sample preparation of the pellet is the same sample preparation method as used for the mice brains, while the sample preparation for the supernatant is the same sample preparation method as used for mice serum, as described in the bio-analytical section below.

The distribution was calculated as follows:

$$
\text { Fraction }(\%)=\frac{M_{\text {tissue }}}{M_{\text {capillaries }}+M_{\text {parenchyma }}} \times 100
$$

where $\mathrm{M}_{\text {tissue }}$ represents the amount of spilanthol in the capillaries, respectively parenchyma; $M_{\text {capillaries }}$ the amount of spilanthol in the capillaries and $M_{\text {parenchyma }}$ the amount of spilanthol in the parenchyma.

\section{Brain-to-blood transport}

To evaluate the efflux of spilanthol out of the brain, an in vivo method previously described was used [29]. Briefly, after anesthetizing the ICR-CD-1 mice using a $40 \%(w / V)$ urethane solution $(3 \mathrm{~g} / \mathrm{kg})$, the skin of the skull was removed. Thereafter, a hole was made into the lateral ventricle using a $22 \mathrm{G}$ needle marked with tape at $2 \mathrm{~mm}$ at the following coordinates: $1 \mathrm{~mm}$ lateral and $0.34 \mathrm{~mm}$ posterior to the bregma. $1 \mu \mathrm{l}$ of the $4 \mathrm{mg} / \mathrm{ml}$ spilanthol dose solution as used for the blood-to-brain influx experiment was injected intracerebroventriculary (ICV) using a syringe pump (KDS100, KR analytical, Cheshire, UK) at a speed of $360 \mu \mathrm{l} / \mathrm{h}$ for $10 \mathrm{~s}$. At specified time points postinjection (1, 3, 5, 10, 12.5 and $15 \mathrm{~min})$, mice were decapitated. Prior to decapitation, blood was collected from the abdominal aorta. Serum was obtained by centrifuging the blood at $10000 \mathrm{~g}$ during $15 \mathrm{~min}$ at $21^{\circ} \mathrm{C}$ and brains were collected. The efflux brain half-life $\left(\mathrm{t}_{1 / 2, \text { brain }}\right)(\mathrm{min})$ was calculated from the linear regression of the natural logarithm of the spilanthol concentration in brain $(\mathrm{ng} / \mathrm{g})$ versus time as follows: $t_{1 / 2, \text { brain }}=\ln (2) / k_{\text {out }}$, where $k_{\text {out }}$ $\left(\mathrm{min}^{-1}\right)$ is defined as the efflux rate constant calculated as the negative value of the slope of the linear regression, applying first order kinetics.

\section{Bio-analytics}

\section{Serum sample preparation}

$60 \mu \mathrm{l}$ of the serum samples, $60 \mu \mathrm{l}$ of $4 \%(\mathrm{~V} / \mathrm{V})$ aqueous $\mathrm{H}_{3} \mathrm{PO}_{4}$ solution and $30 \mu \mathrm{l}$ of the IS solution were transferred into a $0.5 \mathrm{ml}$ (LoBind Eppendorf) tube and vortexed. Interfering compounds were removed by solid 
phase extraction using a positive pressure-96 processor (Waters). $100 \mu \mathrm{l}$ (rat serum) or $125 \mu \mathrm{l}$ (mice serum) of the previous sample solution was loaded on the HLB Oasis ${ }^{\circ}$ relution 96 well plate (Waters, Zellik, Belgium), which was preconditioned with $200 \mu \mathrm{l}$ of $\mathrm{MeOH}$ and equilibrated using $200 \mu \mathrm{l}$ of ultrapure water. After the loading step, the HLB Oasis ${ }^{\circ} \mu$ elution plate was washed using $200 \mu \mathrm{l}$ of $5 \%$ $\mathrm{MeOH}$ in $\mathrm{H}_{2} \mathrm{O}$ followed by $200 \mu \mathrm{l}$ of $20 \% \mathrm{MeOH}$ in $\mathrm{H}_{2} \mathrm{O}$. Spilanthol was eluted using two times $25 \mu \mathrm{l} \mathrm{ACN}$. To the eluate, $25 \mu \mathrm{l}$ of a 80:20 (V/V) $\mathrm{H}_{2} \mathrm{O}: \mathrm{MeOH}$ solution was added and analysed with a UPLC-MS ${ }^{2}$ method, as further described.

A basic validation of the bio-analytical method for the quantification of spilanthol in serum was performed, based upon the EMA guideline on bio-analytical method validation (EMEA/CHMP/EWP/192217/2009) [30]. The limit of detection (LoD) $(\mathrm{S} / \mathrm{N}=3)$ and limit of quantification $(\mathrm{LoQ})(\mathrm{S} / \mathrm{N}=10)$ of spilanthol, determined on the reference standard, were calculated as $0.09 \mathrm{ng} / \mathrm{ml}$ and $0.31 \mathrm{ng} /$ $\mathrm{ml}$, respectively, which correspond to $0.17 \mathrm{ng} / \mathrm{ml}$ and $0.58 \mathrm{ng} / \mathrm{ml}$ in rat serum, respectively. The LoD and LoQ of spilanthol in mouse serum were $0.048 \mathrm{ng} / \mathrm{ml}$ and $0.16 \mathrm{ng} /$ $\mathrm{ml}$, respectively. A matrix factor of 1.1 was observed for spilanthol in rat and mouse serum. The quantification of spilanthol in the rat serum samples was performed using a matrix spiked calibration curve $\left(R^{2}=0.9998\right)$. Linearity was assured in a working range from $0.31 \mathrm{ng} / \mathrm{ml}$ up to $101 \mathrm{ng} /$ $\mathrm{ml}$, corresponding to $0.58 \mathrm{ng} / \mathrm{ml}$ to $189 \mathrm{ng} / \mathrm{ml}$ in rat serum. The quantification of spilanthol in the mouse serum samples was performed using a one-point calibration curve with a spilanthol standard in 40:33.33:26.67 (V/V/V) MeO$\mathrm{H}: \mathrm{ACN}: \mathrm{H}_{2} \mathrm{O}$. The accuracy of the references used for the calibration curves with the pre-extracted spiked matrix samples and the QC reference pre-extracted spiked matrix samples conformed to the specification limits $(<15 \%$ of the nominal value and for the lower limit of quantification (LLoQ) $<20 \%$ of the nominal value), except for the LLoQ used for the validation of spilanthol in mouse serum (>20\% of the nominal value). These values are slightly higher than the specification limits given by the EMA in their guidelines for formal bio-analytical method validation, but are still acceptable for our purposes in the discovery phase. Precision was expressed as the coefficient of variation $(\mathrm{CV})$. The within-run $\mathrm{CV}$ value did not exceed $15 \%$ for the pre-extracted spiked matrix samples. Also the LLoQ did not exceed $20 \%$ and are thus all conform to the specification limits. The recovery in rat serum was $102.1 \%(18.8 \mathrm{ng} / \mathrm{ml}$ to $189 \mathrm{ng} / \mathrm{ml}$ in serum concentration range), calculated from the slopes of the preextracted and post-extracted spiked matrix samples. The recovery in mouse serum was $113.3 \%$ (3 to $257 \mathrm{ng} / \mathrm{ml}$ in serum concentration range). No significant carry-over was observed ( $<20 \%$ of LLoQ spilanthol and $<5 \%$ for IS). The selectivity was conform to the specification limits (placebo rat serum $<20 \%$ of LLoQ spilanthol and $<5 \%$ for IS).

\section{Brain sample preparation}

For the analysis of the mice brain samples, the weighed brains were transferred into a test tube and crushed. $1.0 \mathrm{ml}$ of the IS solution in ACN was added, followed by shaking during $4 \mathrm{~h}$ at $110 \mathrm{rpm}$ at room temperature using an Eppendorf centrifuge 5810 (Eppendorf, Rotselaar, Belgium). The test tube was centrifuged at $250 \mathrm{~g}$ for $5 \mathrm{~min}$ and $800 \mu \mathrm{l}$ of the supernatant was transferred into an Eppendorf tube. Thereafter, a second centrifugation was performed at $20000 \mathrm{~g}$ during $5 \mathrm{~min}$ at room temperature. $750 \mu$ of the supernatant was evaporated to dryness under nitrogen and $175 \mu \mathrm{l}$ 90:10 (V/V) $\mathrm{H}_{2} \mathrm{O}: \mathrm{ACN}$ was added to redissolve spilanthol. Thereafter, $160 \mu \mathrm{l}$ of this solution was loaded on the HLB Oasis ${ }^{\oplus} \mu$ elution 96 well plate. The same washing and elution steps were used as for the serum samples.

Again, a basic validation of the bio-analytical method for the quantification of spilanthol in brains was performed, based upon the EMA guideline on bio-analytical method validation (EMEA/CHMP/EWP/192217/2009) [29]. The LoD and LoQ of spilanthol were $6.30 \mathrm{pg} / \mathrm{g}$ in brain and $21.0 \mathrm{pg} / \mathrm{g}$ in brain, respectively. Ion enhancement (matrix factor $=1.38>1$ ) was observed for the quantification of spilanthol in mice brains. Hence, quantification of spilanthol in the brain samples was performed using the matrix spiked calibration curve $\left(R^{2}=0.9986\right)$. Linearity was assured in a working range of $0.107 \mathrm{ng} / \mathrm{ml}$ to $175 \mathrm{ng} /$ $\mathrm{ml}$ spilanthol, corresponding to $21.0 \mathrm{pg} / \mathrm{g}$ to $34.3 \mathrm{ng} / \mathrm{g}$ in brain. The accuracy of the references used for the calibration curves with the pre-extracted spiked matrix samples conformed to the specification limits $(<15 \%$ of the nominal value), except for the LLoQ used for the validation of spilanthol in brains ( $>20 \%$ of the nominal value), but was still acceptable for our purposes in the discovery phase. The within-run CV value did not exceed $15 \%$ for the preextracted spiked samples. Also the LLoQ did not exceed $20 \%$ and are thus all conform to the limits. The recovery in mouse brains was $72.7 \%$ (0.92 to $98.10 \mathrm{ng} / \mathrm{g}$ brain concentration range).

\section{UPLC-MS ${ }^{2}$ method}

Quantification of spilanthol was performed using a UPLC$\mathrm{MS}^{2}$ method, which was developed on an Acquity UPLC coupled to a Xevo ${ }^{\text {Tm }}$ TQ-S mass spectrometer (MS) (Waters, Zellik, Belgium) with electrospray ionisation source and a triple quadrupole mass analyser. An Acquity UPLC RP C18 column (Waters, $50 \times 2.1 \mathrm{~mm}, 1.7 \mu \mathrm{m}$ ) with a suitable guard column was used. The sample compartment was kept constant at $5{ }^{\circ} \mathrm{C}$, while the column temperature was maintained at $30{ }^{\circ} \mathrm{C} .2 \mu \mathrm{l}$ of the sample was injected and the flow rate was set to $0.5 \mathrm{ml} / \mathrm{min}$. A mobile phase was 
applied using solvent A (0.1 \% FA in 30:70 (V/V) $\left.\mathrm{H}_{2} \mathrm{O}: \mathrm{MeOH}\right)$ and solvent $\mathrm{B}(0.1 \% \mathrm{FA}$ in $\mathrm{MeOH})$ in gradient mode as follows: $0-1.6 \mathrm{~min}$ 100:0 (V/V) A:B, 1.6-2 min going from 100:0 (V/V) A:B to 0:100 (V/V) $\mathrm{A}: \mathrm{B}, 2-3$ min $0: 100(\mathrm{~V} / \mathrm{V}) \mathrm{A}: \mathrm{B}, 3-3.4$ min going from 0:100 (V/V) A:B to 100:0 (V/V) A:B, 3.4-5 min 100:0 $(\mathrm{V} / \mathrm{V}) \mathrm{A}: \mathrm{B}$. The needle wash solvent was $60: 40(\mathrm{~V} / \mathrm{V})$ DMSO:ACN. The MS was operated in the positive electrospray ionisation mode $\left(\mathrm{ESI}^{+}\right)$, with an optimised capillary voltage of $3.0 \mathrm{kV}$, cone voltage of $50 \mathrm{~V}$ and source offset of $60 \mathrm{~V}$. Source and desolvation temperatures were set at $150{ }^{\circ} \mathrm{C}$ and $500{ }^{\circ} \mathrm{C}$, respectively, while cone and desolvation gas $\left(\mathrm{N}_{2}\right)$ flows were 180 and $1000 \mathrm{l} / \mathrm{h}$, respectively. Acquisition was performed in the multiple reaction monitoring (MRM) mode with $\mathrm{m} / \mathrm{z} 222.15$ to $\mathrm{m} / \mathrm{z} 80.96$ transition. The applied collision energy was $20 \mathrm{eV}$ (collision gas $=$ argon). Data were acquired and analysed through MassLynx ${ }^{\circ}$ software (V4.1 SCN 843, Waters).

\section{Results}

\section{Caco-2 cell permeability}

Propranolol was used as a positive control and a $\mathrm{P}_{\mathrm{app}, \mathrm{ab}}$ value of $19.1 \cdot 10^{-6} \mathrm{~cm} / \mathrm{s}$ was obtained, which is in good agreement with the values reported in literature [31]. Atenolol served as the negative control and a lower permeability was observed compared to propranolol. Spilanthol was able to diffuse through the Caco-2 cell monolayer from the apical-to-basolateral side, as well as from the basolateral- to-apical side. Figure 2 shows the percentages of spilanthol permeated through the Caco-2 cells versus time plot with DS1 and DS2.

The percentage of the applied spilanthol which permeated through the Caco-2 cells from the apical-to-basolateral membrane after $120 \mathrm{~min}$ is $79.8 \%$ (or $3.20 \mu \mathrm{g}$ spilanthol) with DS1 and $64.3 \%$ (or $2.47 \mu$ g spilanthol) with DS2. In the opposite direction, the percentage of spilanthol which permeated through the Caco- 2 cells from the basolateral-to-apical membrane after $120 \mathrm{~min}$ is $32.1 \%$ (or $3.86 \mu \mathrm{g}$ spilanthol) with DS1 and $21.6 \%$ (or $2.49 \mu \mathrm{g}$ spilanthol) with DS2.

The apparent permeability coefficient $\left(\mathrm{P}_{\text {app }}\right)$ of spilanthol obtained with DS1 and DS2 from the apical-to-basolateral side is $8.42 \pm 0.59 \cdot 10^{-5} \mathrm{~cm} / \mathrm{s}($ mean $\pm \mathrm{SD}, n=2)$ and 5.61 $\pm 0.54 \cdot 10^{-5} \mathrm{~cm} / \mathrm{s}$ (mean $\left.\pm \mathrm{SD}, n=2\right)$, respectively. The $\mathrm{P}_{\text {app }}$ of spilanthol obtained with DS1 and DS2 was also determined from the basolateral-to-apical side and is $10.21 \pm$ $0.46 \cdot 10^{-5} \mathrm{~cm} / \mathrm{s}($ mean $\pm \mathrm{SD}, n=2)$ and $5.20 \pm 0.06 \cdot 10^{-5}$ $\mathrm{cm} / \mathrm{s}$ (mean $\pm \mathrm{SD}, n=2$ ), respectively. The efflux ratio for spilanthol with DS1 and DS2 is 1.21 and 0.93, respectively, while the uptake ratio for spilanthol with DS1 and DS2 is 0.82 and 1.08 , respectively.

\section{Oral gavage experiment}

Figure 3 represents the rat serum data after oral gavage of spilanthol, fitting a one compartmental model with the mean concentration of spilanthol at each time point.

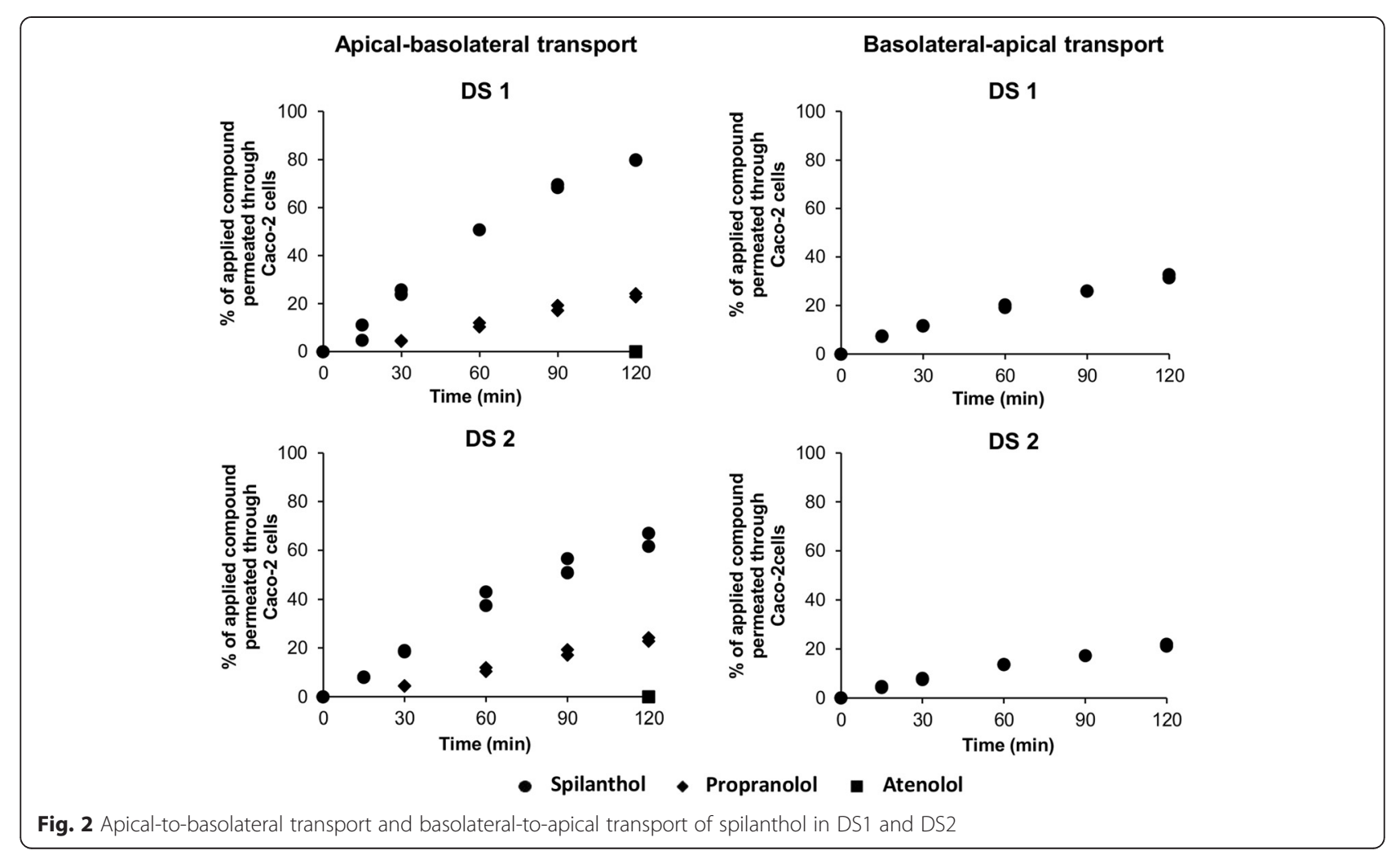


These results of the in vivo experiment confirm the in vitro Caco- 2 cell monolayer results of spilanthol.

From these data, the elimination rate constant and the elimination half-life were calculated as $0.61 \mathrm{~h}^{-1}$ and $1.13 \mathrm{~h}$, respectively.

\section{Blood-brain barrier transport kinetics of spilanthol}

The blood-to-brain transport of spilanthol was investigated. The negative and the positive control confirmed the validity of the BBB test. The $K_{1}$ value of BSA (negative control) was $0.12 \mu \mathrm{l} /(\mathrm{g} \cdot \mathrm{min})$, while the $\mathrm{K}_{1}$ value of the positive control dermorphin was $0.26 \mu \mathrm{l} /(\mathrm{g} \cdot \mathrm{min})$, both consistent with previous data $[29,32]$. The multiple time regression data indicated that spilanthol crosses the blood-brain barrier. In Fig. 4, the ratio of the concentration of spilanthol in brain and serum is plotted versus the exposure time. Furthermore, the kinetic influx data of ${ }^{125}$ I-BSA with or without the surfactant/so-solvents were not significant different, indicating that the surfactant and co-solvents did not affect the BBB integrity (data not shown).

The MTR data of spilanthol were fitted using a biphasic model, based on the modified Gjedde-Patlak equation according to Wong et al. [26]. A rapid but highly significant influx of spilanthol into the brains was observed with a unidirectional influx rate $\left(\mathrm{K}_{1}\right)$ of $796 \mu \mathrm{l} /(\mathrm{g} \cdot \mathrm{min})$. The tissue brain distribution volume $\left(\mathrm{V}_{\mathrm{g}}\right)$ is $652 \mu \mathrm{l} / \mathrm{g}$.

The curve reached a plateau-phase after about $10 \mathrm{~min}$ exposure time and can be explained by efflux of spilanthol out of the brain.

At the same time, also the elimination kinetics of spilanthol in serum were evaluated in the mice model. The serum profile of spilanthol follows a one compartmental model. The concentration of spilanthol at time zero was $3.05 \mu \mathrm{g} / \mathrm{ml}$ and an elimination rate constant and elimination half-life of $0.22 \mathrm{~min}^{-1}$ and $3.16 \mathrm{~min}$ were obtained.

\section{Capillary depletion}

The capillary depletion method was used to study the distribution of spilanthol i.e. the part that was taken up by the brain and the part which was trapped in the endothelial cells of the brain capillaries. A high brain penetration of spilanthol was found: about $98 \%$ of spilanthol (corresponding to $137.8 \mu \mathrm{l} / \mathrm{g}$ ) was found in the brain parenchyma and only about $2 \%$ of spilanthol (corresponding to $2.4 \mu \mathrm{l} / \mathrm{g}$ ) that entered the brain remained in the brain capillaries.

\section{Brain-to-blood transport kinetics of spilanthol}

The efflux properties of spilanthol out of the brain were investigated by quantifying the concentration of spilanthol in the brain after intracerebroventricular injection of the dose solution. When evaluating the transport of spilanthol out of the brain into the blood, it is confirmed that there is also efflux of spilanthol (Fig. 5), which can explain the rapid plateauing observed when evaluating the blood-tobrain kinetics during the influx experiment (Fig. 4). The efflux transfer constant $\mathrm{k}_{\text {out }}$ was derived from the absolute value of the slope of the natural logarithm of the concentration of spilanthol in the brain (ng/g) versus the experimental time curve ( $\mathrm{min})$. The $\mathrm{k}_{\text {out }}$ calculated for spilanthol was $0.11 \mathrm{~min}^{-1}$, equal to a $\mathrm{t}_{1 / 2 \text {,brain }}$ of $6.4 \mathrm{~min}$.

\section{Discussion}

In this study, the in vitro Caco- 2 cell monolayer permeability of spilanthol, a 2,6,8-triene NAA, was investigated using two different dose solutions. The permeation level of spilanthol through Caco- 2 cells was the highest from the apical-to-basolateral side: $64-80 \%$ of the applied DS permeated through Caco-2 cells after 120 min (absorptive direction). Spilanthol, applied as DS2, did not appear to better permeate the Caco-2 cells compared to spilanthol applied as DS1, suggesting that co-solvents (vitamin E-TPGS, PEG 400, PG) did not enhance the

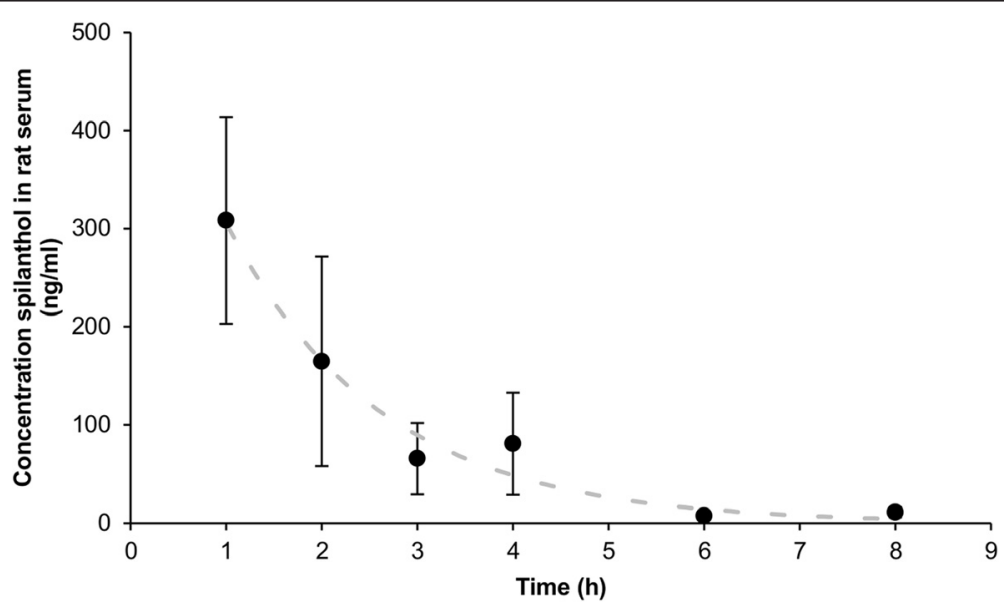

Fig. 3 Concentration of spilanthol in rat serum as a function of time after oral gavage, one compartmental model $(n=3$, mean, error bars: SEM) 


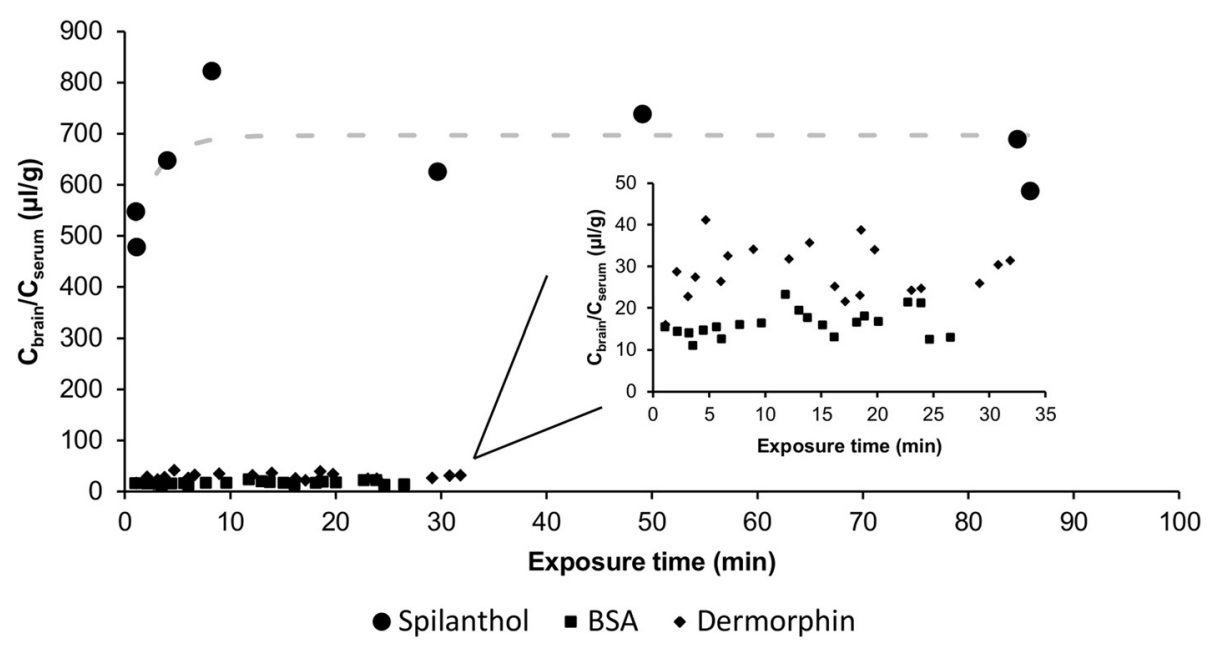

Fig. 4 Brain influx results of spilanthol, BSA and dermorphin (MTR in mice)

permeation of spilanthol through the cell monolayer. Both dose solutions did not contain more than $0.5 \%$ ethanol in buffer, as final ethanol concentrations above $2 \%$ can damage the Caco- 2 cell monolayer.

As mentioned earlier, Matthias et al. [15] investigated a different type of NAA, namely the transport of 2-ene and 2,4-diene NAAs through the Caco-2 cell monolayer (dissolved in ethanol and diluted in HEPES buffer, final ethanol concentration did not exceed $2 \%$ ) with $\mathrm{P}_{\text {app }}$ values ranging from $3 \cdot 10^{-6}$ to $3 \cdot 10^{-4} \mathrm{~cm} / \mathrm{s}$. The diversity in $\mathrm{P}_{\text {app }}$ for the different $\mathrm{N}$-alkylamides was correlated to structural variations, with saturation and $\mathrm{N}$-terminal methylation contributing to lowered $\mathrm{P}_{\text {app }}$ values.

The $\mathrm{P}_{\text {app }}$ values obtained for spilanthol in this study were all above $1 \cdot 10^{-6} \mathrm{~cm} / \mathrm{s}$, indicating an almost complete intestinal absorption. Compounds with $\mathrm{P}_{\text {app }}$ values $<1 \cdot 10^{-6}$ $\mathrm{cm} / \mathrm{s}$ show a less readily absorption. The $\mathrm{P}_{\text {app }}$ values obtained for spilanthol in this study $\left(5 \cdot 10^{-5}\right.$ to $\left.10 \cdot 10^{-5} \mathrm{~cm} / \mathrm{s}\right)$ are thus consistent with the structural conclusions reported by Matthias et al. [15] based on the mono- and dieneNAAs from Echinacea plant species.

It has been reported that if there is a more than 2-fold difference in $\mathrm{P}_{\text {app }}$ values between the apical-to-basolateral and the basolateral-to-apical direction, a high probability of active transport exists [33]. In this experiment, for both dose solutions of spilanthol, this difference was less than 2 -fold, indicating that no active transport function can be readily assumed. Studies have proven a correlation between drug permeability coefficients obtained during a Caco-2 cell monolayer experiment and oral absorption in humans $[31,34,35]$. However, as no in vitro model can yet totally mimic the in vivo intestinal barrier, since many factors such as solubility, formulation, chemical composition, $\mathrm{pH}$ of the intestinal secretions, food composition, gastric emptying time, intestinal motility and blood flow play a role [33, 36, 37], an oral gavage experiment in rats was conducted to evaluate the intestinal barrier properties of spilanthol in vivo. Rats are one of the most common

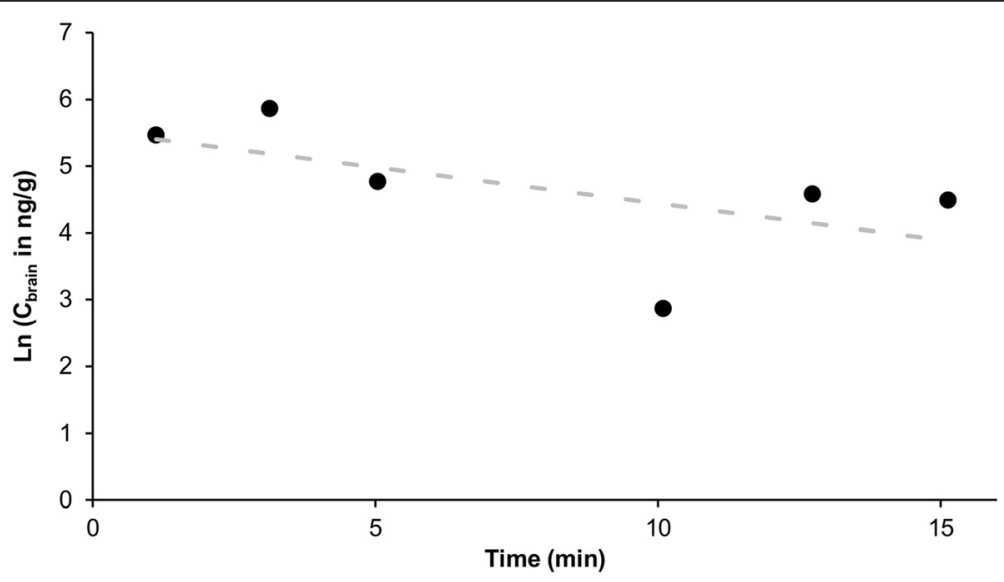

Fig. 5 Brain efflux of spilanthol 
animals used in preclinical oral absorption studies [36] and are generally considered as good animal models towards humans (e.g. F1 modifying factor in permitted daily exposure (PDE) toxicity evaluation is 5 for extrapolation from rats to humans) [38]. Several studies have already shown that there is a good correlation between the absorption of compounds in rat and the absorption in humans $[36,37,39]$. Spilanthol was orally administered to rats in a liquid dose solution containing the same solvents as used for DS2 of the Caco-2 cell permeability experiment, consisting of ethanol, PG, vitamin E-TPGS and PEG400. For the absorption rate, the formulation plays an important role and compounds solubilized in liquid generally absorb faster compared to solid forms. The elimination phase, on the contrary, is independent of the oral dosage form. Vitamin E-TPGS, an esterified vitamin E derivative, was added to the formulation because of its solubilizing and emulsifying properties to enhance the solubility and facilitate the absorption of spilanthol [40, 41]. In this in vivo study, spilanthol was clearly observed in the rat serum and hence, spilanthol was able to diffuse through the gut barrier into the systemic circulation, confirming the in vitro Caco-2 cell results. Spilanthol showed an elimination half-life of $1.13 \mathrm{~h}(63 \mathrm{~min})$, corresponding to similar values reported by Woelkart et al. [17], who investigated the plasma concentration of dodeca-2E,4E,8E,10E/Z-tetraenoic acid isobutylamides from Echinacea via oral gavage in rats, resulting in an elimination half-life of $72 \mathrm{~min}$.

Besides the lipophilicity of the compound, its passive gut-blood permeability is dependent on the charge and molecular size of the compound. Considering the lipophilic $\log \mathrm{P}$ value of 3.39 of spilanthol and the molecular weight of $221.34 \mathrm{~g} / \mathrm{mol}$, it seems that transcellular transport is appropriate for spilanthol [42]. These findings were confirmed in the Caco- 2 cell permeability experiment, which indicated that spilanthol diffused through the cells via passive diffusion. Once in the systemic circulation, the investigated compound can distribute to extravascular compartments such as the brain to exert CNS activity.

Therefore, the present study investigated the bloodbrain barrier transport properties of spilanthol in an in vivo mice experiment. In kinetic $B B B$ research, one of the 'golden' methodologies is the MTR using mice for reasons of costs, handling and animal care. In PDE toxicity evaluation, the F1 modifying factor is 12 for extrapolation from mice to humans [38]. Spilanthol was administered to the mice in a solution containing ethanol, dimethylacetamide and tween 80 in lactated Ringer's solution containing BSA. Dimethylacetamide and ethanol are often used in injectable pharmaceutical formulations as co-solvents to solubilize poorly soluble compounds, while tween 80 is a traditional surfactant $[43,44]$. It is known that tween 80 in high doses up to $30 \mathrm{mg} / \mathrm{kg}$ administered to mice causes blood-brain barrier disruption [45]. In this MTR study, a dose of $3 \mathrm{mg} / \mathrm{kg}$ tween 80 was used. Also ethanol, at a concentration of $1-4 \mathrm{~g} / \mathrm{kg}$, may cause disruption of the $\mathrm{BBB}$ as well [45]. However, in the current study, only $0.04 \mathrm{~g}$ ethanol $/ \mathrm{kg}$ mice was administered. Although transient effects cannot be excluded, our data indicate that the solvents did not affect the BBB integrity. In addition, no toxicity was observed during the experiment. From our results, it is concluded that spilanthol was able to rapidly penetrate the BBB after intravenous administration with a unidirectional influx rate of $796.2 \mu \mathrm{l} /(\mathrm{g} \cdot \mathrm{min})$. This high $K_{1}$ value indicates a high initial influx rate of spilanthol into the brains, which is supported by the lipophilic character of this NAA. Moreover, $98 \%$ of spilanthol was found in the parenchyma of the brains, while only $2 \%$ was trapped in the capillaries, which makes it possible for NAAs to exert CNS effects. Furthermore, significant efflux out of the brain into the blood was also observed.

It was already mentioned in the introduction that Spilanthes acmella extracts showed some central analgesic activities. In general, different central nervous pharmacodynamic activities are attributed to $\mathrm{N}$-alkylamide containing plants. Psychotropic effects (anxiolytic effect) in animals were already found by using alkylamide Echinacea preparations, which was explained by their affinity for the CB receptors. Furthermore, similar to cannabinoids, alkylamides alter immune cell activity, which open perspectives for the treatment of neuroinflammatory diseases $[17,46]$. In addition, capsaicin, the major NAA in hot peppers of the plant genus Capsicum interacts agonistically with the transient receptor potential vanilloid 1 receptor, predominantly expressed in primary afferent fibres and sensory neurones, playing a role in pain sensation $[47,48]$. Another study reported an improvement of amyloid beta(1-42)-induced spatial memory impairment after administration of a $50 \mathrm{mg} / \mathrm{kg}$ and $100 \mathrm{mg} / \mathrm{kg}$ methanolic extract of Piper nigrum fruits by gastric gavage to rats. The plant extract, containing piperine, which is a major alkylamide of black pepper, caused an attenuation of the oxidative stress in the rat hippocampus. Other studies demonstrated analgesic, anticonvulsant, antidepressant, anti-oxidant, anti-inflammatory, protection against neurodegeneration and cognitive enhancing effects of cognitive deficit-like condition of Alzheimer's disease of piperine $[49,50]$.

In addition, in some studies there is an indirect proof of blood-brain barrier influx of $N$-alkylamides. It has been shown that several $\mathrm{N}$-alkylamide containing plants showed activity against epilepsy in animal models. Experiments with medicinal plants such as Anacyclus pyrethrum, Nigella sativa, Ferula gummosa and Pimpinalla anisum were performed to investigate their effect on seizures of epilepsy. It has been shown that the chloroform 
fraction of Anacyclus pyrethrum roots, $100-800 \mathrm{mg} / \mathrm{kg}$ administered intraperitoneally to mice, possess neuropharmacological effects, such as antiseizure activity [51, 52]. Other studies demonstrated the myorelaxation and anticonvulsant activities in mice of the Anacyclus pyrethrum extract as well $[51,53]$. Treatment with capsaicin resulted in a decrease in behavioral seizure activity and body temperature in a kainic acid induced epileptogenesis mice model. Furthermore, anti-oxidant activity in blood increased and the concentrations of IL- $1 \beta$ and TNF- $\alpha$ in the brain lowered [48].

The majority of the studies reported in literature only look at the effects of in vivo or in vitro studies and no exposure data are available. Therefore, more detailed studies about exposure levels are required. In the current study, spilanthol concentrations in brains and serum were quantitatively measured and we demonstrated a high influx of spilanthol into the brain, indicating a possible role in CNS diseases.

\section{Conclusion}

In this study, it is demonstrated that spilanthol is able to cross the Caco- 2 cell monolayer in vitro and the intestinal membrane in vivo in rats after oral administration. After absorption and reaching the systemic circulation, spilanthol is able to rapidly and significantly cross the BBB in mice. Spilanthol also showed a significant efflux out of the brain, which explains partly the biphasic behavior of the influx. These results suggest possible medicinal applications for spilanthol in central nervous system diseases from a pharmacokinetic point of view.

\section{Additional file}

Additional file 1: The NMR spectra of isobutyldecanamide. (PDF $284 \mathrm{~kb}$ )

\section{Acknowledgments}

The authors gratefully acknowledge Robertet (Grasse, France) for the gift of the Spilanthes acmella (L.) L. extract.

\section{Funding}

The authors like to thank the Special Research Fund of Ghent University (BOF $01 D 23812$ to Lien Taevernier and BOF 01 D38811 to Sofie Stalmans).

\section{Availability of data and materials}

The datasets supporting the conclusions of this article are included within the article and the additional file.

\section{Authors' contributions}

LV and BDS conceived the study and design; PT, CB, LT, SS, KP approved the study conception and design; MR synthesised the analytical internal standard; LV, TJ, EW, NB performed the experiments; LV, BDS did the analysis and interpretation of the data; LT, EW critically reviewed the data; LV wrote the manuscript; all co-authors critically reviewed and approved the final version of the manuscript and BDS had the overall supervision and finally approved the manuscript.

\section{Competing interests}

The authors declare that they have no competing interests.

\section{Consent for publication}

Not applicable.

\section{Ethics approval and consent to participate}

All mice animal experiments were performed in accordance with the Ethical Committee principles of laboratory animal welfare as approved by our institute (Ghent University, Faculty of Veterinary Medicine, no. EC2012/157 and no. EC2014/128). The Wistar rats were bred in Bharat Serum and Vaccines pvt. Ltd, Thane, India (registration number 103/99/CPCSEA) and kept for the experiments at C. U. Shah College of Pharmacy, SNDT Women's University, Santacruz, Mumbai, India (registration number 39/99/CPCSEA).

\section{Author details}

${ }^{1}$ Drug Quality and Registration (DruQuaR) group, Faculty of Pharmaceutical Sciences, Ghent University, Ottergemsesteenweg 460, B-9000 Ghent, Belgium. ${ }^{2}$ C.U. Shah College of Pharmacy, S.N.D.T. Women's University, Santacruz (W), Mumbai 400 049, India. ${ }^{3}$ Department of Medical Imaging and Small Animal Orthopedics, Faculty of Veterinary Medicine, Ghent University, Salisburylaan 133, B-9820 Merelbeke, Belgium. ${ }^{4}$ Department of Comparative Physiology and Biometrics, Faculty of Veterinary Medicine, Ghent University, Salisburylaan 133, B-9820 Merelbeke, Belgium. ${ }^{5}$ Laboratory of Medicinal Chemistry, Faculty of Pharmaceutical Sciences, Ghent University, Ottergemsesteenweg 460, B-9000 Ghent, Belgium.

Received: 8 December 2015 Accepted: 3 June 2016

Published online: 13 June 2016

\section{References}

1. Wu SH, Sun CR, Pei SF, Lu YB, Pan YJ. Preparative isolation and purification of amides from the fruits of Piper longum $L$. by upright counter-current chromatography and reversed-phase liquid chromatography. J Chromatogr A. 2004;1040:193-204.

2. Barnes J, Anderson LA, Gibbons S, Phillipson JD. Echinacea species (Echinacea angustifolia (DC.) Hell., Echinacea pallida (Nutt.) Nutt., Echinacea purpurea (L.) Moench): a review of their chemistry, pharmacology and clinical properties. J Pharm Pharmacol. 2005;57:929-54.

3. Wang Y, Wang B, McNeil B, Harvey LM. Maca: an Andean crop with multipharmacological functions. Food Res Int. 2007;40:783-92.

4. Yang X. Aroma constituents and alkylamides of red and green huajiao (Zanthoxylum bungeanum and Zanthoxylum schinifolium). J Agric Food Chem. 2008;56:1689-96.

5. Boonen J, Bronselaer A, Nielandt J, Veryser L, De Tré G, De Spiegeleer B. Alkamid database: Chemistry, occurance and functionality of plant $\mathrm{N}$ alkylamides. J Ethnopharmacol. 2012;142(3):563-90.

6. Coulon D, Faure L, Salmon M, Wattelet V, Bessoul JJ. N-Acylethanolamines and related compounds: Aspects of metabolism and functions. Plant Sci. 2012;184:129-40. 
7. Sharma V, Boonen J, Chauhan NS, Thakur M, De Spiegeleer B, Dixit VK. Spilanthes acmella ethanolic flower extract: LC-MS alkylamide profiling and its effects on sexual behavior in male rats. Phytomedicine. 2011;18:1161-9.

8. Prachayasittikul V, Prachayasittikul S, Ruchirawat S, Prachayasittikul V. High therapeutic potential of Spilanthes acmella: a review. Excli Journal. 2013;12: 291-312.

9. Chakraborty A, Devi RKB, Rita S, Sharatchandra K, Singh TI. Preliminary studies on antiinflammatory and analgesic activities of Spilanthes acmella in experimental animal models. Indian J Pharmacol. 2004;36(3):148-50.

10. Barman S, Sahu N, Deka S, Dutta S. Anti Inflamatory and Analgesic Activity of Leaves of Spilanthes Acmella (Elsa) in Experimental Animal Models. Pharmacologyonline. 2009;1:1027-34.

11. Rios MY, Aguilar-Guadarrama AB, Gutiérrez MC. Analgesic activity of affinin, an alkamide from Heliopsis longipes (Compositae). J Ethnopharmacol. 2007; 110(2):364-7.

12. Boonen J, Baert B, Burvenich C, Blondeel P, De Saeger S, De Spiegeleer B. LC-MS profiling of N-alkylamides in Spilanthes acmella extract and the transmucosal behaviour of its main bio-active spilanthol. J Pharm Biomed Anal. 2010;53(3):243-9.

13. Boonen J, Baert B, Roche N, Burvenich C, De Spiegeleer B. Transderma behaviour of the $\mathrm{N}$-alkylamide spilanthol (affinin) from Spilanthes acmella (Compositae) extracts. J Ethnopharmacol. 2010;127:77-84.

14. De Spiegeleer B, Boonen J, Malysheva SV, Mavungu JD, De Saeger S, Roche N, Blondeel P, Taevernier L, Veryser L. Skin penetration enhancing properties of the plant N-alkylamide spilanthol. J Ethnopharmacol. 2013;148(1):117-25.

15. Matthias A, Blancfield JT, Penman KG, Toth I, Lang CS, De Voss JJ, Lehmann RP. Permeability studies of alkylamides and caffeic acid conjugates from Echinacea using a Caco-2 cell monolayer. J Clin Pharm and Ther. 2004;29:7-13.

16. Abbott NJ, Patabendige AA, Dolman DE, Yusof SR, Begley DJ. Structure and function of the blood-brain barrier. Neurobiol Dis. 2010;37(1):13-25.

17. Woelkart K, Frye RF, Derendorf H, Bauer R, Butterweck V. Pharmacokinetics and tissue distribution of dodeca-2E,4E,8E,10E/Z-tetraenoic acid isobutylamides after oral administration in rats. Planta Med. 2009;75(12):1306-13.

18. Hubatsch I, Ragnarsson EGE, Artursson P. Determination of drug permeability and prediction of drug absorption in Caco-2 monolayers. Nat Protoc. 2007;2: 2111-9.

19. Cattoor K, Bracke M, Deforce D, De Keukeleire D, Heyerick A. Transport of hop bitter acids across intestinal Caco-2 cell monolayers. J Agric Food Chem. 2010;58:4132-40.

20. Tavelin S, Gråsjö J, Taipalensuu J, Ocklind G, Artursson P. Applications of Epithelial Cell Culture in Studies of Drug Transport. Epithelial Cell Culture Protocols. Methods Mol Biol. 2002;188:223-72.

21. Van Dorpe S, Bronselaer A, Nielandt J, Stalmans S, Wynendaele E, Audenaert K, Van De Wiele C, Burvenich C, Peremans K, Hsuchou H, De Tré G, De Spiegeleer B. Brainpeps: the blood-brain barrier peptide database. Brain Struct Funct. 2012;217:687-718

22. Stalmans S, Gevaert B, Wynendaele E, Nielandt J, De Tré G, Peremans K, Burvenich C, De Spiegeleer B. Classification of peptides according to their blood-brain barrier influx. Protein Pept Lett. 2015;22(9):768-75.

23. Stalmans S, Bracke N, Wynendaele E, Gevaert B, Peremans K, Burvenich C, Polis I, Spiegeleer B. Cell-Penetrating Peptides Selectively Cross the BloodBrain Barrier In Vivo. PloS One. 2015;10(10):e0139652. doi:10.1371/journal. pone.0139652.

24. Gjedde A. High-affinity and low-affinity transport of D-glucose from blood to brain. J Neurochem. 1981;36(4):1463-71.

25. Patlak CS, Blasberg RG, Fenstermacher JD. Graphical evaluation of blood-tobrain transfer constants from multiple-time uptake data. J Cerebr Blood F Met. 1983;3(1):1-7.

26. Wong DF, Gjedde A, Wagner Jr HN. Quantification of neuroreceptors in the living human brain I. Irreversible binding of ligands. J Cereb Blood Flow Metab. 1986;6:137-46.

27. Triguero D, Buciak J, Pardridge WM. Capillary depletion method for quantification of blood-brain barrier transport of circulating peptides and plasma proteins. J Neurochem. 1990:54:1882-8.

28. Gutierrez EG, Banks WA, Kastin AJ. Murine tumor necrosis factor alpha is transported from blood to brain in the mouse. J Neuroimmunol. 1993;47: 169-76.

29. Stalmans S, Wynendaele E, Bracke N, Knappe D, Hoffman R, Peremans K, Polis I, Burvenich C, De Spiegeleer B. The blood-brain barrier transport of short proline-rich antimicrobial peptides. Protein Pept Lett. 2014;21(4): 399-406.
30. European Medicines Agency (EMA): Guideline on bio-analytical method validation. EMEA/CHMP/EWP/192217/2009.

31. Yazdanian M, Glynn SL, Wright JL, Hawi A. Correlating Partitioning and Caco-2 Cell Permeability of Structurally Diverse Small Molecular Weight Compounds. Pharmaceut Res. 1998;15(9):1490-4.

32. Kastin AJ, Akerstrom V. Entry of exendin-4 into brain is rapid but may be limited at high doses. Int J Obes. 2003;27:313-8.

33. Heikkinen AT, Korjamo T, Mönkkönen J. Modelling of drug disposition kinetics in in vitro intestinal absorption cell models. Nordic Pharmacological Society. Basic Clin Pharmacol Toxicol. 2009;106:180-8.

34. Artursson P, Karlsson J. Correlation between oral drug absorption in humans and apparent drug permeability coefficients in human intestinal epithelial (Caco-2) cells. Biochem Biophys Res Commun. 1991;175(3):880-5.

35. Irvine JD, Takahashi L, Lockhart K, Cheong J, Tolan JW, Selick HE, Grove JR. MDCK (Madin-Darby canine kidney) cells: a tool for membrane permeability screening. J Pharm Sci. 1999;88(1):28-33.

36. Zhao YH, Abraham MH, Le J, Hersey A, Luscombe CN, Beck G, Sherborne B, Cooper I. Evaluation of rat intestinal absorption data and correlation with human intestinal absorption. Eur J Med Chem. 2003;38(3):233-43.

37. Cao X, Gibbs ST, Fang L, Miller HA, Landowski CP, Shin HC, Lennernas H, Zhong Y, Amidon GL, Yu LX, Sun D. Why is it challenging to predict intestinal drug absorption and oral bioavailability in human using rat model. Pharm Res. 2006;23(8):1675-86.

38. European Medicines Agency (EMA): CVMP/VICH/502/99. VICH topic GL18. Impurities: residual solvents. 2000.

39. Caldwell GW, Masucci JA, Yan Z, Hageman W. Allometric Scaling of Pharmacokinetic Parameters in Drug Discovery: Can human CL, Vss and $t_{1 / 2}$ be predicted from In-vivo Rat Data? Eur J Drug Metab Pharmacokinet. 2004; 29(2):133-43.

40. Li J, Yang B, Levons J, Pinnamaneni S, Raghavan K. Phase behavior of TPGSPEG400/1450 systems and their application to liquid formulation: a formulation platform approach. J Pharm Sci. 2011;100(11):4907-21.

41. Guo Y, Luo J, Tan S, Otieno BO, Zhang Z. The applications of Vitamin E TPGS in drug delivery. Eur J Pharm Sci. 2013;49(2):175-86.

42. Fan J, de Lannoy IAM. Pharmacokinetics. Biochem Pharmacol. 2014;87(1):93-120.

43. Guest RT. Dimethylacetamide. In: Rowe RC, Sheskey PJ, Quinn ME, editors. Handbook of pharmaceutical excipients. Sixthth ed. Grayslake: Pharmaceutical Press; 2009. p. 241.

44. Pramanick S, Singodia D, Chandel V. Excipient selection in parenteral formulation development. Pharma Times. 2013;45(3):65-77.

45. Pardridge WM. The Blood-Brain Barrier: Bottleneck in Brain Drug Development. NeuroRx. 2005;2(1):3-14

46. Hohmann J, Rédei D, Forgo P, Szabó P, Freund TF, Haller J, Bojnik E, Benyhe S. Alkamides and a neolignan from Echinacea purpurea roots and the interaction of alkamides with G-protein-coupled cannabinoid receptors. Phytochemistry. 2011;72(14-15):1848-53.

47. Alawi K, Keeble J. The paradoxical role of the transient receptor potential vanilloid 1 receptor in inflammation. Pharmacol Ther. 2010;125:181-95.

48. Lee TH, Lee JG, Yon JM, Oh KW, Baek IJ, Nahm SS, Lee BJ, Yun YW, Nam SY. Capsaicin prevents kainic acid-induced epileptogenesis in mice. Neurochem Int. 2011;58(6):634-40

49. Hritcu L, Noumedem JA, Cioanca O, Hancianu M, Kuete V, Mihasan M. Methanolic extract of Piper nigrum fruits improves memory impairment by decreasing brain oxidative stress in amyloid beta(1-42) rat model of Alzheimer's disease. Cell Mol Neurobiol. 2014;34(3):437-49.

50. Rasool M, Malik A, Qureshi MS, Manan A, Pushparaj PN, Asif M, Qazi MH, Aamer AM, Kamal MA, Gan SH, Sheikh IA. Recent Updates in the Treatment of Neurodegenerative Disorders Using Natural Compounds. Evid Based Complement Alternat Med. 2014;article ID 979730, doi http://dx.doi.org/10. 1155/2014/979730.

51. Fard MA, Shojaii A. Efficacy of Iranian traditional medicine in the treatment of epilepsy. Biomed Res Int. 2013;article ID 692751, doi 10.1155/2013/692751.

52. Zaidi SMA, Pathan SA, Singh S, Jamil S, Ahmad FJ, Khar RK. Anticonvulsant, Anxiolytic and Neurotoxicity Profile of Aqarqarha (Anacyclus pyrethrum) DC (Compositae) Root Ethanolic Extract. Pharmacol Pharm. 2013;4:535-41.

53. Gautam OP, Verma S, Jain SK. Anticonvulsant and myorelaxation activity of Anacyclus pyrethrum DC. (Akarkara) root extract. Pharmacologyonline. 2011;1:121-5. 